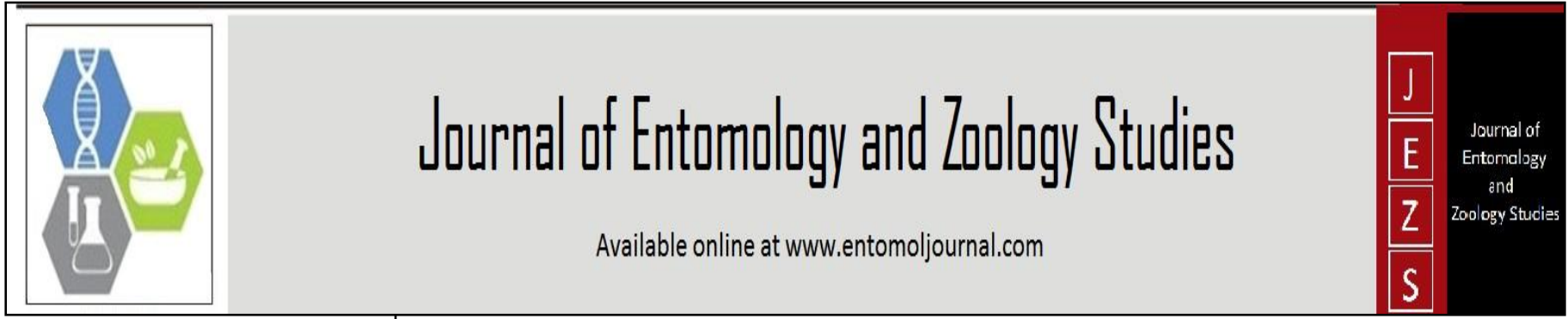

E-ISSN: 2320-7078

P-ISSN: 2349-6800

www.entomoljournal.com JEZS 2020; 8(6): 721-725 (C) $2020 \mathrm{JEZS}$

Received: 12-09-2020

Accepted: 18-10-2020

\section{S Vijayashanthi}

M. Sc scholar (Department of

Nematology), Tamil Nadu

Agricultural University,

Coimbatore, Tamil Nadu, India.

\section{A Shanthi}

Professor and Head (Department

of Nematology), Tamil Nadu

Agricultural University,

Coimbatore, Tamil Nadu, India

\section{T Raguchander}

Dean, Centre for Students

Welfare, Tamil Nadu

Agricultural University,

Coimbatore, Tamil Nadu, India

\section{PG Kavitha}

Assistant Professor (Department of Nematology), Tamil Nadu Agricultural University,

Coimbatore, Tamil Nadu, India
Corresponding Author:

S Vijayashanthi

M. Sc scholar (Department of

Nematology), Tamil Nadu

Agricultural University,

Coimbatore, Tamil Nadu, India.

\section{Interaction effect of root knot nematode, Meloidogyne incognita and wilt fungus, Fusarium solani in cucumber}

\section{S Vijayashanthi, A Shanthi, T Raguchander and PG Kavitha}

\author{
DOI: https://doi.org/10.22271/j.ento.2020.v8.i6j.7929
}

\begin{abstract}
The interaction between root knot nematode, Meloidogyne incognita and wilt fungus, Fusarium solani was studied in cucumber under glasshouse condition. A pot experiment was conducted to evaluate the effect and pathogenesis of nematode and fungus individually as well as various combinations viz., inoculation of nematode 7 days prior to fungus, inoculation of fungus 7 days prior to nematode, simultaneous inoculation of nematode and fungus. The results showed that significant reduction of plant growth parameters were observed in combination of nematode inoculated 7 days prior to fungus followed by simultaneous inoculation. Nematode population in the soil, number of galls, number of females and number of egg masses in the roots were higher in the treatment nematode alone followed by nematode inoculated 7 days prior to fungus. Though, nematode reproduction was high in the treatment of nematode alone, the disease incidence was more in nematode inoculated 7 days prior to fungus where the nematode acts as predisposer for other pathogens including fungus. The study was concluded that the effect of nematode inoculated 7 days prior to fungus shows high per cent of wilt disease incidence in cucumber than other combinations.
\end{abstract}

Keywords: Meloidogyne incognita, Fusarium solani, nematode wilt disease complex

\section{Introduction}

Cucumber (Cucumis sativus) is one of the most popular vegetables in India and widely cultivated plant in the gourd family, Cucurbitaceace. It is a creeping vine that bears cucumiform fruits that are used as vegetables. It is grown all over the world due to its high nutritive value and good source of vitamins and minerals. China is the world largest cucumber producer in the world whose production is 64.8 million tons (Food and Agriculture Organization). In India, largest producer Haryana produces 274.40 MT of cucumber during 2017-18 (National Horticulture Board). Continuous growing of cucurbitaceous plants in pandal system makes more disease incidence. Also in polyhouse cultivation, the incidence of disease in cucumber is high. Cucumber plants get affected by several biotic stresses like fungus, bacteria, virus, nematodes and insects. Fusarium solani, a soil borne pathogen cause wilt disease in cucumber plants. Root knot nematode, Meloidogyne incognita is important and more devasting plant parasite in India ${ }^{[1]}$ and it has wide host range of more than 3000 plants including cucurbits. Cucumber is more susceptible to root knot nematodes and Fusarium wilt pathogen. Root knot nematode acts as a primary invader of Fusarium fungus and cause wilt disease complex. The disease complex was first reported by Atkinson, 1892, where the wilt resistant cotton becomes more susceptible in presence of root knot nematode. Nematode increases the incidence of disease through the entry of other pathogens like fungus and makes disease complex in the plants. A study which observed that root knot nematode, $M$. incognita interacts which Fusarium solani produce wilt disease complex in tomato ${ }^{[5]}$ and the nematode, Meloidogyne javanica interrelated with two soil borne fungus, Fusarium solani and Rhizoctonia solani which produce disease complex in eggplant ${ }^{[10]}$. Interaction effect of Meloidogyne incognita and Fusarium oxysporum cause disease severity and more yield loss in black gram ${ }^{[3]}$. Considering the disease complex caused by nematode and pathogens in various crop plants, a research was made to study the interaction effect of Meloidogyne incognita and Fusarium solani for causing disease complex and its damage intensity in cucumber. 


\section{Materials and methods}

2.1 Isolation of root knot nematode, Meloidogyne incognita

The root knot nematodes were isolated from the infested roots of cucumber showing the symptoms of galls or knots. The infested roots are washed in running tap water for 2 to 3 minutes to remove the soil particles adhered on the roots. Then, roots were cut into small pieces and observed for the presence of galls. The females were collected from the galls by teasing out the galls with help of needle under binocular stereo zoom microscope.

\subsection{Morphological identification of Meloidogyne incognita} through Posterior Cuticular Pattern (PCP)

Species of root knot nematodes were confirmed with the help of posterior cuticular pattern through staining of infested roots with acid - fuchsin lactophenol followed by destaining with plain lactophenol for $24-72 \mathrm{hrs}{ }^{[4]}$. The isolated nematode was confirmed as $M$. incognita through PCP given in the figure. It consists of distinct high dorsal arch composed of smooth to wavy striae. Some striae fork near the lateral lines but distinct lateral incisures are not present ${ }^{[4]}$.

\subsection{Pure culture of root- knot nematode, Meloidogyne incognita}

Pure culture of $M$. incognita required for the experimental studies was maintained in the cucumber plants. After confirmation of root knot nematode species, the egg masses were collected from the infested roots of cucumber and placed in a beaker containing distilled water. Then it was allowed to hatch for a week. Twenty days old cucumber seedlings of Hercules hybrid were planted in the earthen pots containing sterile pot mixture. Pot mixture consists of red soil: sand: FYM in the ratio of $2: 1: 1$. Second stage juveniles $\left(\mathrm{J}_{2}\right)$ are inoculated near rhizosphere region of cucumber plants maintained in the glasshouse. Egg masses required for the experiment are collected from the roots by uprooting the plants carefully. The egg masses were picked under stereo zoom microscope using forceps and transferred to beaker containing water for hatching which was used for further studies. The nematodes were multiplied and maintained separately as pure culture in the glasshouse, Department of Nematology, Tamil Nadu Agricultural University, Coimbatore.

\subsection{Isolation of fungus}

In a random survey, infected cucumber plants showing wilted symptoms are collected. The roots were cut into small pieces $(0.5-1.0 \mathrm{~cm})$ length, washed thoroughly in fresh water and sterilized with $0.1 \%$ mercuric chloride for 3 min followed by three subsequent washings with sterile distilled water for 3 times and drained the water through sterilized filter paper. Then, the sterilized root bits were placed on the Petri plate containing Potato Dextrose Agar medium. The Petri dishes are incubated at $27 \pm 1{ }^{\circ} \mathrm{C}$. After incubation, the pathogen was purified by single hyphal tip method ${ }^{[12]}$ and maintained on PDA medium.

\subsection{Characterization and pathogenicity of Fusarium fungus}

2.5.1 Morphological identification of Fusarium spp.

The fungus was morphologically identified by taking samples of mycelia fungus from sub cultures. The slides containing fungus was examined under light microscope (Labomed IVU 5100) and confirmed the presence of microconidia and macroconidia. From the old cultures, resting spore chlamydospores were also recorded.

\subsubsection{Molecular characterization of Fusarium spp.}

The isolated fungus was characterized by PCR (polymerase chain reaction) method. PCR amplification of ITS region of Fusarium isolate was carried out using universal primer pair viz., Internal Transcribed Spacer, ITS 1 (5'CTTGGTCATTTAGAGGAAGTAA - 3') and ITS 4 (5'TCCTCCGTTATTGATATGC - 3').

\subsection{Mass multiplication of fungus}

The pure culture of isolated Fusarium solani was maintained on PDA at $27 \pm 1^{\circ} \mathrm{C}$. For mass multiplication, the pure cultures of fungus were grown in sterilized sand maize medium in the ratio 9:1 (sand: broken maize). The bags were incubated in the room temperature at $27 \pm 1^{\circ} \mathrm{C}$ for 15 days.

\subsection{Pathogenicity of Fusarium}

The pathogenic capability of the isolated fungi was carried out under glasshouse condition. Fifteen days old seedlings were planted in the pot containing pot mixture. The isolated test fungus multiplied in the sand maize medium was applied at the rate of $5 \mathrm{~g} / \mathrm{kg}$ of pot mixture. The plants without inoculation of fungus served as a control. The pots were irrigated regularly. The severity of disease and percentage of wilt incidence were recorded after one month of inoculation. Re-isolation was carried out from inoculated plants showing the disease symptoms and the isolated fungus was compared with the original culture used.

\subsection{Interaction of Meloidogyne incognita and Fusarium} solani in cucumber under glasshouse condition.

A pot culture experiment was conducted under glasshouse condition to study the interaction effect of root knot nematode and wilt pathogen. The experiment was laid out in a completely randomized block design (CRD) replicated four times with six treatments. Earthen pots of $3 \mathrm{~kg}$ capacity were filled with sterilized pot mixture and surface sterilized hybrid seeds of cucumber, Hercules were sown and 25 days old seedlings were transplanted in each pot at one plant per pot. The treatments were i. M. incognita alone ii. Fusarium solani alone iii.

M. incognita inoculated 7 days prior to Fusarium solani inoculation. iv. Fusarium solani inoculated 7 days prior to $M$. incognita inoculation v. simultaneous inoculation of $M$. incognita and Fusarium solani vi. Uninoculated control. The second stage juveniles of $M$. incognita were inoculated @ $1000 \mathrm{~J}_{2} / \mathrm{kg}$ of soil and $F$. solani inoculated at the rate of $5 \mathrm{~g} / \mathrm{kg}$ of soil. After 60 days of inoculation, observations were made on root population of nematode include no. of. galls, egg masses and eggs/egg masses, gall index of 1-5 scale (Root knot index: $1=0$ galls; $2=1-25$ galls; $3=26-50$ galls; $4=$ 51-75 galls; $5=>75$ per cent galls per root system) ${ }^{[6]}$. Nematode populations in soil were assessed by Cobb's decanting sieving method ${ }^{[2]}$ followed by Modified Baermann funnel technique. Per cent wilt incidence due to fungus was recorded using number of wilt infected plants/total number of plants taken for observation.

\section{Results}

3.1 Identification of nematode species associated with cucumber

Meloidogyne species collected from cucumber was identified 
by cuticular markings present in the perenial area of matured female. The PCP were observed with high dorsal arch composed of smooth to wavy striae (Plate 1) and it is confirmed as Meloidogyne incognita.

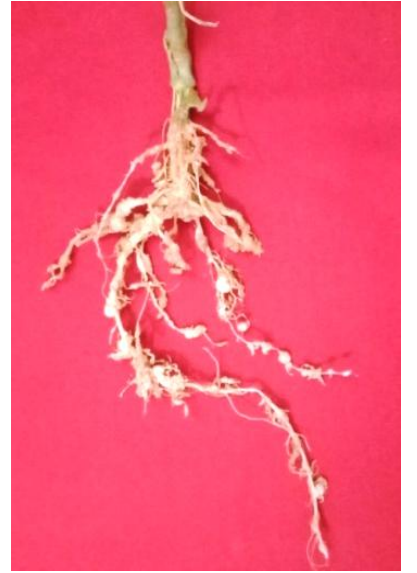

a. RKN infested root of cucumber

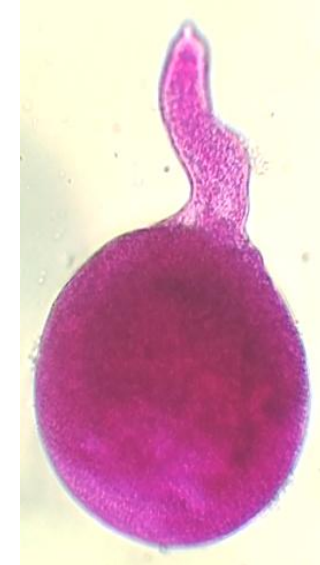

b. Adult female

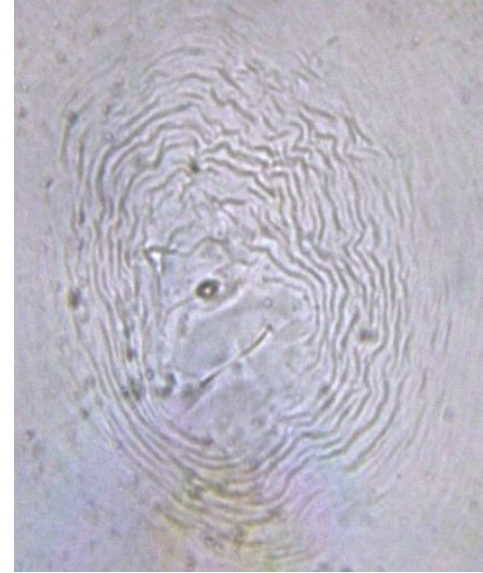

c. Perineal pattern of $M$. incognita

Plate 1: Morphological identification of Root knot nematode

3.2 Identification of Fusarium species associated with cucumber

The fungus was confirmed as Fusarium by its conidial structures and microspores, macrospores and chlamydospores production of fungus (Plate 2). PCR was performed to identify the Fusarium spp. using universal primers ITS 1 and ITS 4 . The results revealed that, the isolates were amplified with amplicon size of approximately $560 \mathrm{bp}$ corresponding to 18S-28S rDNA region (Plate 3). The PCR product were resolved on $1.2 \%$ agarose, purified and sequenced at Barcode Biosciences, Bangalore, India. The sequence analysis of an isolate revealed that it had nucleotide sequence identity $99.5 \%$ homology with Fusarium solani. Thus the pathogen causing wilt disease in cucumber was confirmed as Fusarium solani.

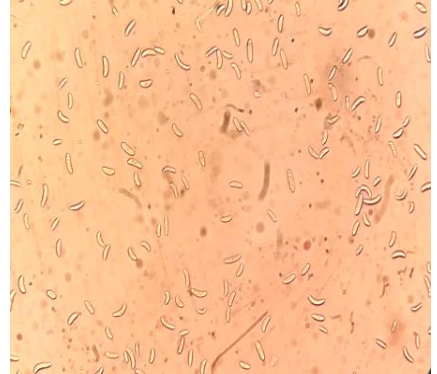

a. Microconidia

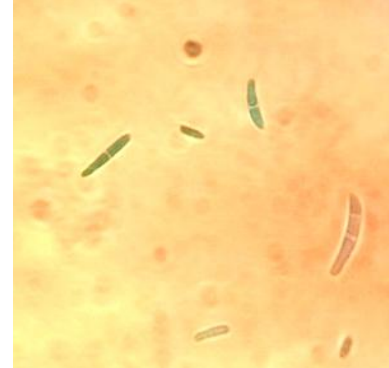

b. Macroconidia

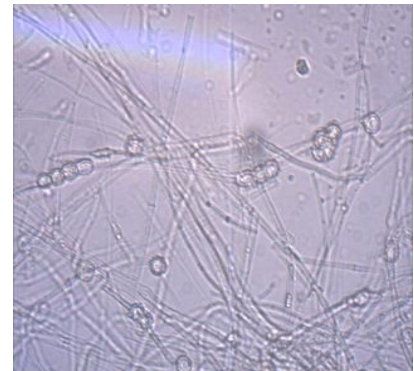

c. Chlamydospores

Plate 2: Morphological identification of Fusarium spp

12

600

500

400

300

200

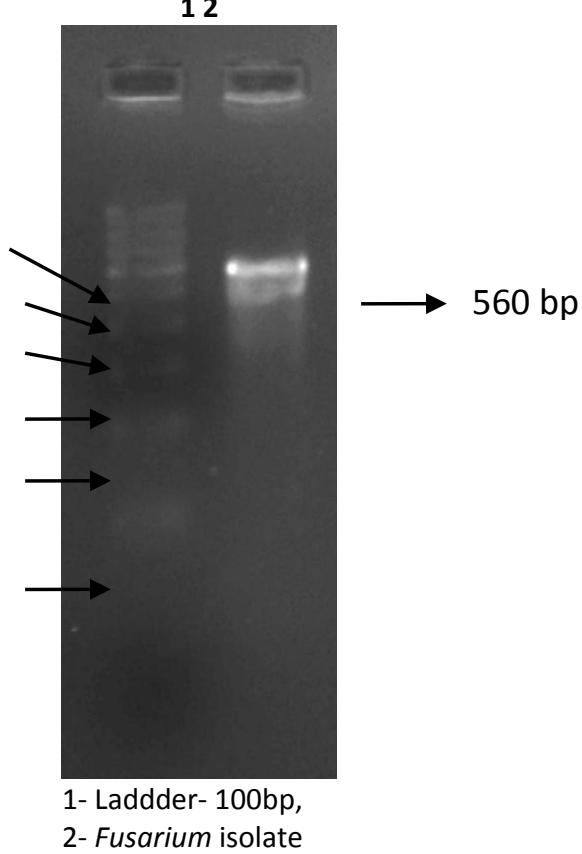

Plate 3: Molecular characterization of Fusarium species 


\subsection{Interaction effect of Meloidogyne incognita and Fusarium solani}

The interaction effect of $M$. incognita and $F$. solani on cucumber was studied under glasshouse condition and the results furnished on table 1 . The results indicates that parameters, nematode inoculated 7 days prior to fungus having significantly reduced plant height $(96.50 \mathrm{~cm})$ followed by the treatment concominant inoculation of fungus and nematode which was found to be $105.25 \mathrm{~cm}$ when compared to control $(152.25 \mathrm{~cm})$. Minimum root length was observed in nematode inoculated prior to fungus $(18.25 \mathrm{~cm})$ and followed by simultaneous inoculation of nematode and fungus $(21.00$ $\mathrm{cm})$ compared to control $(43.75 \mathrm{~cm})$. Minimum fresh shoot weight $(15.43 \mathrm{~g})$, dry shoot weight $(8.25 \mathrm{~g})$, fresh root weight $(3.58 \mathrm{~g})$ and dry root weight $(1.73 \mathrm{~g})$ also highly reduced in the treatment, nematode inoculation prior to the fungus than control.

The data represented in the table 2 revealed that number of juveniles per $250 \mathrm{~g}$ of soil (344.75), number of females per 5 $\mathrm{g}$ of root (74.5) and number of egg masses per $5 \mathrm{~g}$ of root (52.5) were maximum in the treatment nematode alone. It was followed by the treatment nematode inoculated 7 days prior to fungus where number of Juveniles/250 $\mathrm{g}$ of soil was 323.25 , number of females $/ 5 \mathrm{~g}$ of root was 56.75 and number of egg masses $/ 5 \mathrm{~g}$ of root was 42.00 . There were no nematode juveniles, females and egg mass in the treatment fungus alone and untreated control. The wilt incidence has significantly increased in all the treatments compared to the control. The maximum wilt incidence $(100 \%)$ was recorded in the nematode inoculated 7 days prior to the fungal pathogen followed by concominant inoculation of $M$. incognita and $F$. solani which was recorded $75 \%$ incidence.

Table 1: Interactive effect of Meloidogyne incognita and Fusarium solani on plant growth parameters in cucumber

\begin{tabular}{|c|c|c|c|c|c|c|}
\hline \multirow{3}{*}{ Treatments } & \multicolumn{6}{|c|}{ Plant growth parameters } \\
\hline & \multicolumn{3}{|c|}{ Shoot } & \multicolumn{3}{|c|}{ Root } \\
\hline & $\begin{array}{l}\text { Length } \\
(\mathbf{c m})\end{array}$ & $\begin{array}{c}\text { Fresh weight } \\
\text { (g) }\end{array}$ & $\begin{array}{l}\text { Dry weight } \\
\text { (g) }\end{array}$ & $\begin{array}{c}\text { Length } \\
(\mathrm{cm})\end{array}$ & $\begin{array}{c}\text { Fresh weight } \\
(\text { g) }\end{array}$ & $\begin{array}{l}\text { Dry weight } \\
\text { (g) }\end{array}$ \\
\hline $\mathrm{T}_{1}$ - Nematode alone & $\begin{array}{l}124.50^{\mathrm{e}} \\
(18.23) \\
\end{array}$ & $\begin{array}{r}28.85^{\mathrm{d}} \\
(35.78) \\
\end{array}$ & $\begin{array}{c}14.38^{\mathrm{e}} \\
(51.47) \\
\end{array}$ & $\begin{array}{l}35.00^{c} \\
(20.00) \\
\end{array}$ & $\begin{array}{c}8.28^{\mathrm{d}} \\
(46.78) \\
\end{array}$ & $\begin{array}{c}5.18^{c} \\
(52.55) \\
\end{array}$ \\
\hline $\mathrm{T}_{2}$ - Fungus alone & $\begin{array}{l}119.25^{\mathrm{d}} \\
(21.67)\end{array}$ & $\begin{array}{l}27.08^{\mathrm{d}} \\
(39.73)\end{array}$ & $\begin{array}{l}13.25^{\mathrm{d}} \\
(55.27)\end{array}$ & $\begin{array}{l}29.25^{\mathrm{b}} \\
(33.14)\end{array}$ & $\begin{array}{l}7.45^{\mathrm{cd}} \\
(52.09)\end{array}$ & $\begin{array}{l}4.35^{\mathrm{b}} \\
(60.27)\end{array}$ \\
\hline $\begin{array}{l}\mathrm{T}_{3} \text { - Nematode inoculation } 7 \text { days prior to } \\
\text { fungus }\end{array}$ & $\begin{array}{l}96.50^{\mathrm{a}} \\
(36.62)\end{array}$ & $\begin{array}{l}15.43^{\mathrm{a}} \\
(65.66)\end{array}$ & $\begin{array}{l}8.25^{\mathrm{a}} \\
(72.15)\end{array}$ & $\begin{array}{l}18.25^{\mathrm{a}} \\
(58.29)\end{array}$ & $\begin{array}{c}3.58^{\mathrm{a}} \\
(77.01)\end{array}$ & $\begin{array}{l}1.73^{\mathrm{a}} \\
(84.20)\end{array}$ \\
\hline $\begin{array}{c}\mathrm{T}_{4-} \text { Fungus inoculation } 7 \text { days prior to } \\
\text { nematode }\end{array}$ & $\begin{array}{l}113.00^{\mathrm{c}} \\
(25.78)\end{array}$ & $\begin{array}{l}23.90^{c} \\
(46.80)\end{array}$ & $\begin{array}{l}11.38^{\mathrm{c}} \\
(61.60)\end{array}$ & $\begin{array}{l}26.75^{\mathrm{b}} \\
(38.86)\end{array}$ & $\begin{array}{c}6.65^{\mathrm{c}} \\
(57.23)\end{array}$ & $\begin{array}{l}3.35^{\mathrm{b}} \\
(69.40)\end{array}$ \\
\hline $\begin{array}{l}\text { T5- Simultaneous inoculation nematode and } \\
\text { fungus }\end{array}$ & $\begin{array}{l}105.25^{\mathrm{b}} \\
(30.87)\end{array}$ & $\begin{array}{r}19.03^{b} \\
(57.65)\end{array}$ & $\begin{array}{l}9.38^{\mathrm{b}} \\
(68.35)\end{array}$ & $\begin{array}{l}21.00^{\mathrm{a}} \\
(52.00)\end{array}$ & $\begin{array}{l}4.55^{\mathrm{b}} \\
(70.74)\end{array}$ & $\begin{array}{c}1.85^{\mathrm{a}} \\
(83.10)\end{array}$ \\
\hline $\mathrm{T}_{6-}$ Uninoculated control & $152.25^{\mathrm{f}}$ & $44.93^{\mathrm{e}}$ & $29.63^{f}$ & $43.75^{\mathrm{d}}$ & $15.55^{\mathrm{e}}$ & $10.95^{\mathrm{d}}$ \\
\hline $\mathrm{CD}(\mathrm{p}=0.05)$ & 2.55 & 0.72 & 0.53 & 0.73 & 1.98 & 1.24 \\
\hline SEd & 1.20 & 0.34 & 0.25 & 0.34 & 0.9 & 0.59 \\
\hline
\end{tabular}

*Values are mean of four replications

**Values in parantheses are percent decrease over control

Table 2: Interactive effect of Meloidogyne incognita and Fusarium solani on nematode reproduction in cucumber

\begin{tabular}{|c|c|c|c|c|c|}
\hline \multirow[b]{2}{*}{ Treatments } & \multicolumn{4}{|c|}{ Nematode reproduction } & \multirow{2}{*}{$\begin{array}{l}\text { Wilt disease incidence } \\
(\%)\end{array}$} \\
\hline & $\begin{array}{c}\mathrm{J}_{2} / 250 \mathrm{~g} \text { of } \\
\text { soil }\end{array}$ & $\begin{array}{c}\text { Female/ } 5 \mathrm{~g} \text { of } \\
\text { root }\end{array}$ & $\begin{array}{c}\text { Egg mass/ 5g of } \\
\text { root }\end{array}$ & $\begin{array}{c}\text { Root knot } \\
\text { index }\end{array}$ & \\
\hline $\mathrm{T}_{1}$ - Nematode alone & $\begin{array}{l}344.75^{\mathrm{a}} \\
(18.57)\end{array}$ & $\begin{array}{l}74.50^{\mathrm{a}} \\
(8.66) \\
\end{array}$ & $\begin{array}{c}52.5^{\mathrm{a}} \\
(7.27) \\
\end{array}$ & 5.00 & 0.00 \\
\hline $\mathrm{T}_{2}$ - Fungus alone & $\begin{array}{l}0.00^{\mathrm{e}} \\
(0.71)\end{array}$ & $\begin{array}{l}0.00^{\mathrm{e}} \\
(0.71)\end{array}$ & $\begin{array}{l}0.00^{\mathrm{d}} \\
(0.71)\end{array}$ & 0.00 & 50.00 \\
\hline $\begin{array}{c}T_{3} \text { - Nematode inoculation } 7 \text { days prior to } \\
\text { fungus }\end{array}$ & $\begin{array}{l}323.25^{\mathrm{b}} \\
(17.99) \\
\end{array}$ & $\begin{array}{l}56.75^{\mathrm{b}} \\
(7.56)\end{array}$ & $\begin{array}{l}42.00^{\mathrm{b}} \\
(6.50) \\
\end{array}$ & 4.00 & 100.00 \\
\hline $\begin{array}{c}\mathrm{T}_{4} \text { - Fungus inoculation } 7 \text { days prior to } \\
\text { nematode }\end{array}$ & $\begin{array}{l}282.25^{\mathrm{d}} \\
(16.81)\end{array}$ & $\begin{array}{l}25.50^{\mathrm{d}} \\
(5.09)\end{array}$ & $\begin{array}{l}25.00^{c} \\
(5.04)\end{array}$ & 2.75 & 50.00 \\
\hline $\begin{array}{l}\mathrm{T}_{5} \text { - Simultaneous inoculation of nematode } \\
\text { and fungus }\end{array}$ & $\begin{array}{l}302.50^{\mathrm{c}} \\
(17.41)\end{array}$ & $\begin{array}{l}34.75^{\mathrm{c}} \\
(5.93)\end{array}$ & $\begin{array}{l}41.50^{\mathrm{b}} \\
(6.48)\end{array}$ & 3.50 & 75.00 \\
\hline $\mathrm{T}_{6}$ - Uninoculated control & $\begin{array}{l}0.00^{\mathrm{e}} \\
(0.71)\end{array}$ & $\begin{array}{l}0.00^{\mathrm{e}} \\
(0.71)\end{array}$ & $\begin{array}{l}0.00^{\mathrm{d}} \\
(0.71)\end{array}$ & 0.00 & 0.00 \\
\hline $\mathrm{CD}(\mathrm{p}=0.05)$ & 0.40 & 0.38 & 0.49 & & \\
\hline Sed & 0.19 & 0.18 & 0.23 & & \\
\hline
\end{tabular}

*Values are mean of four replications

**Values in parentheses are square root transformed values.

\section{Discussion}

The results of the study revealed that the plant growth was affected in all treatments where the nematode and fungus inoculated to the plant both individually and in combination. But the incidence of disease complex was significantly higher in the treatment where the $M$. incognita inoculated 7 days prior to $F$. solani and shows more synergistic followed by the treatment where both the pathogens inoculated simultaneously. Similar effect was also observed in the protected cultivation of cucumber where the nematode $M$. incognita inoculated 7 days prior to the fungus Fusarium oxysporum $f$. sp. cucumerinum which shows high level of disease incidence followed by concominant inoculation of nematode and fungus than the control ${ }^{[9]}$ and the maximum 
wilt incidence was observed in the treatment where the Meloidogyne incognita was inoculated 15 days prior to the inoculation of Fusarium solani in Bittergourd under pot culture experiment ${ }^{[11]}$. Thus the nematode acts as a primary invader for causing disease complex. It was proved in the study Meena et al. ${ }^{[8]}$ that the nematode acts as a predisposer for the spread of secondary fungal pathogens. The wilt disease was caused by interaction of root knot nematode, Meloidogyne incognita with wilt fungus Fusarium solani in Gerbera.

Although the individual pathogen can reduce plant growth, combined effect of nematode and fungus resulted increased the severity of disease. It was proved in the study Kalaivanan et al. ${ }^{[7]}$. where the sequential and concomitant inoculation of the root knot nematode, Meloidogyne incognita and fungus, Sclerotinia sclerotiorum cause more disease severity than the individual effect of nematode and fungus. In this study, the treatment receiving nematode incolution 7 days prior to fungus shows higher reduction in plant growth parameters and nematode population in soil and root and its reproduction. $M$. incognita acts as a predisposer of $F$. solani which enhances the disease development in cucumber. But the wilt incidence was higher in nematode inoculation prior to fungus and concominant inoculation of fungus and nematode. Thus, present study proved that presence of nematode paves ways for the entry of fungal pathogens which increases wilt disease severity than the individual inoculation of nematodes and fungus in cucumber.

\section{Conclusion}

The present investigation concludes that treatment of root knot nematode Meloidogyne incognita inoculated 7 days prior to the inoculation of Fusarium solani causes maximum per cent wilt disease incidence compared to control. The nematode acts as a primary invader for spread of fungal pathogen. This interaction enhances incidence of wilt diseases and reduce plant growth parameters in cucumber under polyhouse condition. Thus, the study proved that the nematode paves way for entry of fungal pathogens to increase the wilt disease severity in cucumber.

\section{Acknowledgement}

I delivered sincere gratitude to the Department of Nematology in Tamil Nadu Agricultural University, Coimbatore for providing the laboratory research work to carry out the research work.

\section{References}

1. Akram M, Khan MR. Interaction of Meloidogyne incognita and Fusarium oxysporum $f$. sp. lycopersici on tomato. Annals of Plant Protection Sciences. 2006;14(2):448-451.

2. Christie JR, Perry VG. "Removing nematodes from soil". Proceedings of the Helminthological Society of Washington. 1951;18(2):106-108.

3. Dilip Kumar, Jayant Bhatt, Ratan Lal Sharma, Naresh Kumar. Interaction between Meloidogyne incognita and Fusarium oxysporum on Black gram, Vigna mungo L. International Journal of Chemical Studies 2017;5(4):624627.

4. Eisenback JD, Hrischmann H, Sasser JN, Triantaphyllou AC. A guide to the four most common species of rootknot nematodes (Meloidogyne spp.), with a pictorial key. Journal of Nematology. 1981;(12):300-313.
5. Ganaie MA, Khan TA. Studies on the interactive effect of Meloidogyne incognita and Fusarium solani on Lycopersicon esculentum, Mill. International Journal of Botany. 2011;7(2):205-208.

6. Heald C, Bruton BD, Davis RM. "Influence of Glomus intraradices and soil phosphorus on Meloidogyne incognita infecting Cucumis melo". Journal of Nematology 1989;21(1):69.

7. Kalaivanan R, Dhivya M, Karthikeyan G, Devrajan K, Manonmani K. Interaction of White Rot Fungus [Sclerotinia sclerotiorum (Lib.) de Bary] and Root-Knot Nematode [Meloidogyne incognita (Kofoid and White) Chit.]. Cabbage (Brassica oleracea L.). International Journal of Current Microbiology and Applied Science 2017;6(9):641-647.

8. Meena KS, Ramyabharathi SA, Raguchander T, Jonathan EI. Meloidogyne incognita and Fusarium oxysporum interaction in Gerbera. African Journal of Microbiology Research 2015;9(18):1281-1285.

9. Patil J, Goel SR, Yadav. Effect of Meloidogyne incognita and Fusarium oxysporum $f$. sp. cucumerinum on cucumber grown under protected cultivation. Journal of Entomology and Zoology Studies 2018;6(1):1004-1007

10. Siddiqui IA, Shaukat SS. Spatial pattern analysis of root rot-root knot disease complex in an infested eggplant field. Nematologia Mediterranea. 2002;30:131-135

11. Sreegayathri E, Karthikeyan G, Rajendran L, Shanthi A, Jegathesh RR. Effect of Root Knot Nematode (Meloidogyne incognita) Infestation on Severity of Wilt (Fusarium solani) in Bitter Gourd and its Management. Madras Agricultural Journal. 2018;105:579-588.

12. Tutte J. Plant pathological methods: Fungi and Bacteria, Minneapolis, Minn. Burgess Publishing Com, 1969, 239. 